\title{
PLANT RECORDS FOR \\ SASKATCHEWAN - 1973 VERSION \\ STARRING PORCUPINE MOUNTAIN
}

\author{
by JOHN HUDSON*
}

I have been sending in communications to the Blue Jay since 1956 about having found plants hitherto unreported in Saskatchewan. Surely, readers may well mutter, an end must come of all this - the fellow is going to run up against the law of diminishing returns sometime. However if one picks an unfamiliar territory of varied topography off the beaten track and visits it, there is a good chance one will find something one hasn't seen before, no matter how long one has been botanizing.

Thus it was that in summer, 1973, I thought I'd have a look at Porcupine Mountain. Access is provided by a forestry road traversing it from north to south parallel to and a few miles west of the Manitoba line, from Armit on Highway No. 3 to Arran on Highway No. 49. From the $1: 250,000$ N.T.S. map $63 \mathrm{C}$ (which does not show this access road) one could see that Porcupine Mountain reaches an altitude of 2,600 ft. above sea level some 14 miles south of Armit (alt. $\left.1,000^{\prime}\right)$. There is a drop of about 1,100 feet in the first 4 miles north from this highest spot, after which the other 500' of altitude is lost more gently over the remaining 10 miles to Armit, which hamlet lies in the Manitoba lowland, the old Lake Agassiz bottom. Indeed, Lake Agassiz beach ridges may be

*103 Richmond Crescent,

Saskatoon, Saskatchewan. spotted protruding from the swampy forest some 3-4 miles south of Armit, But going the other way, south, from this highest spot altitude is lost only imperceptibly; one traverses some 35 miles of forested rolling hills before coming out in farmland north of Arran. This road, it should be noted, becomes impassable after rain.

My botanizing was done mostly near the summit, just behind (south of) the steep drop. The high precipitation due to the altitude along with good drainage made Rowan Trees (Sorbus decora Sarg.) abundant on the slope of the "mountain." Actually the landform is that of a plateau covered with glacial drift, making up one of the segments of the Manitoba Escarpment.

Three species not reported for Saskatchewan were found here, plus assorted already reported species that I personally had not seen before. I might have done even better had I not been forced to leave hastily and ahead of schedule every time (three trips) on account of rain.

The first of the novelties was Milium effusum L, Millet-grass, collected as Hudson No. 2858, July 1, 1973, dominant in old clearing in rich mixed forest, Porcupine Mountain $52^{\circ} 38^{\prime} \mathrm{N}$, alt. about 2,600'.

This is a large upstanding grass about the size and build of the common Awnless Brome (Bromus inermis Leyss), but with the paniculately borne 


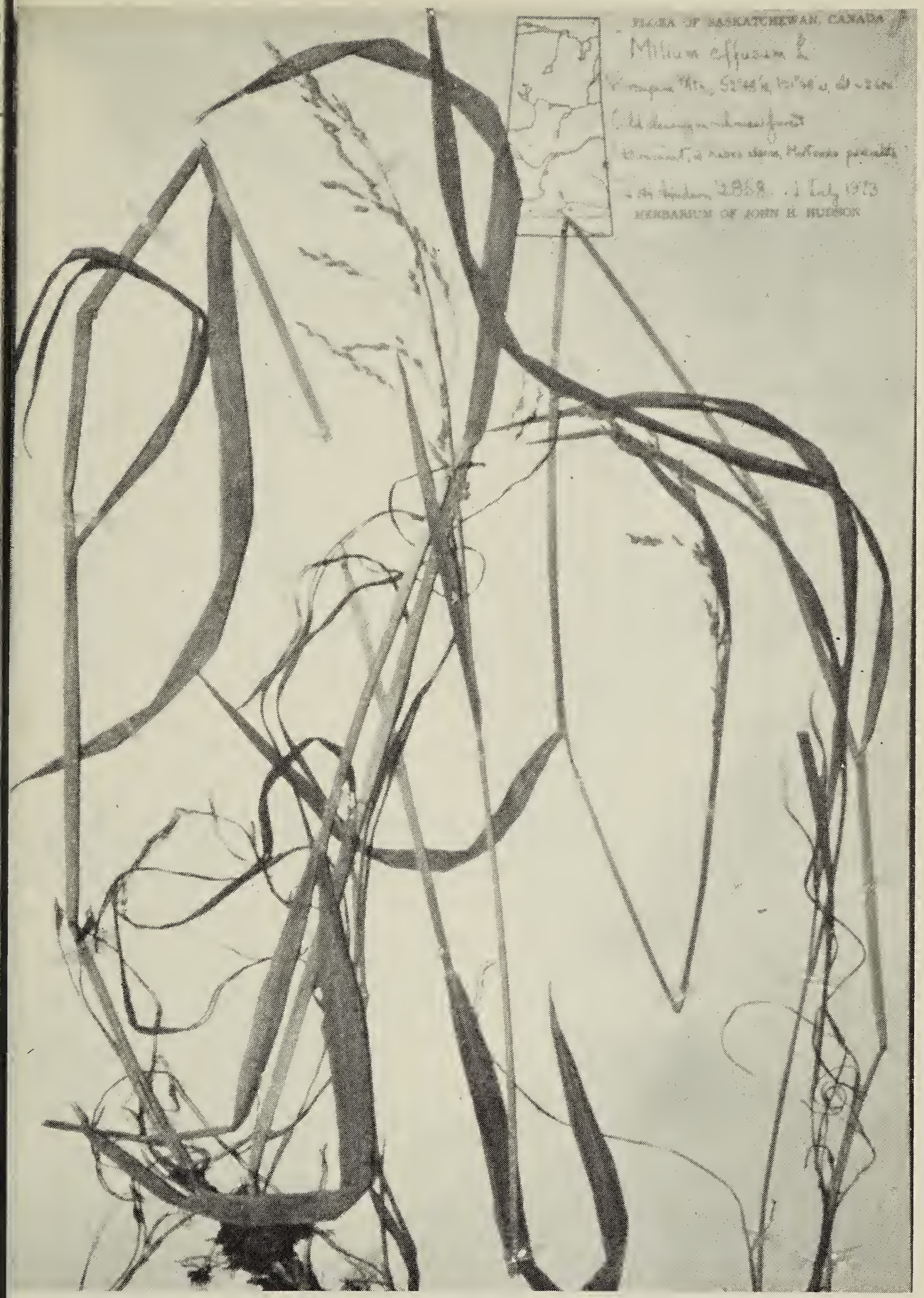

Fig. 1. Mount about 11"X 17" Millet-grass Milium effusum

spikelets one-flowered (Fig. 1). The lemma and palea of the flower are hard, smooth and shiny like those of Proso Millet (Panicum miliaceum L.). Although no relation to the millets, the resemblance impressed Linnaeus enough to name this grass Milium. The grass is reported for Manitoba by Boivin." Scoggan" discounted old Manitoba reports in spite of the fact 

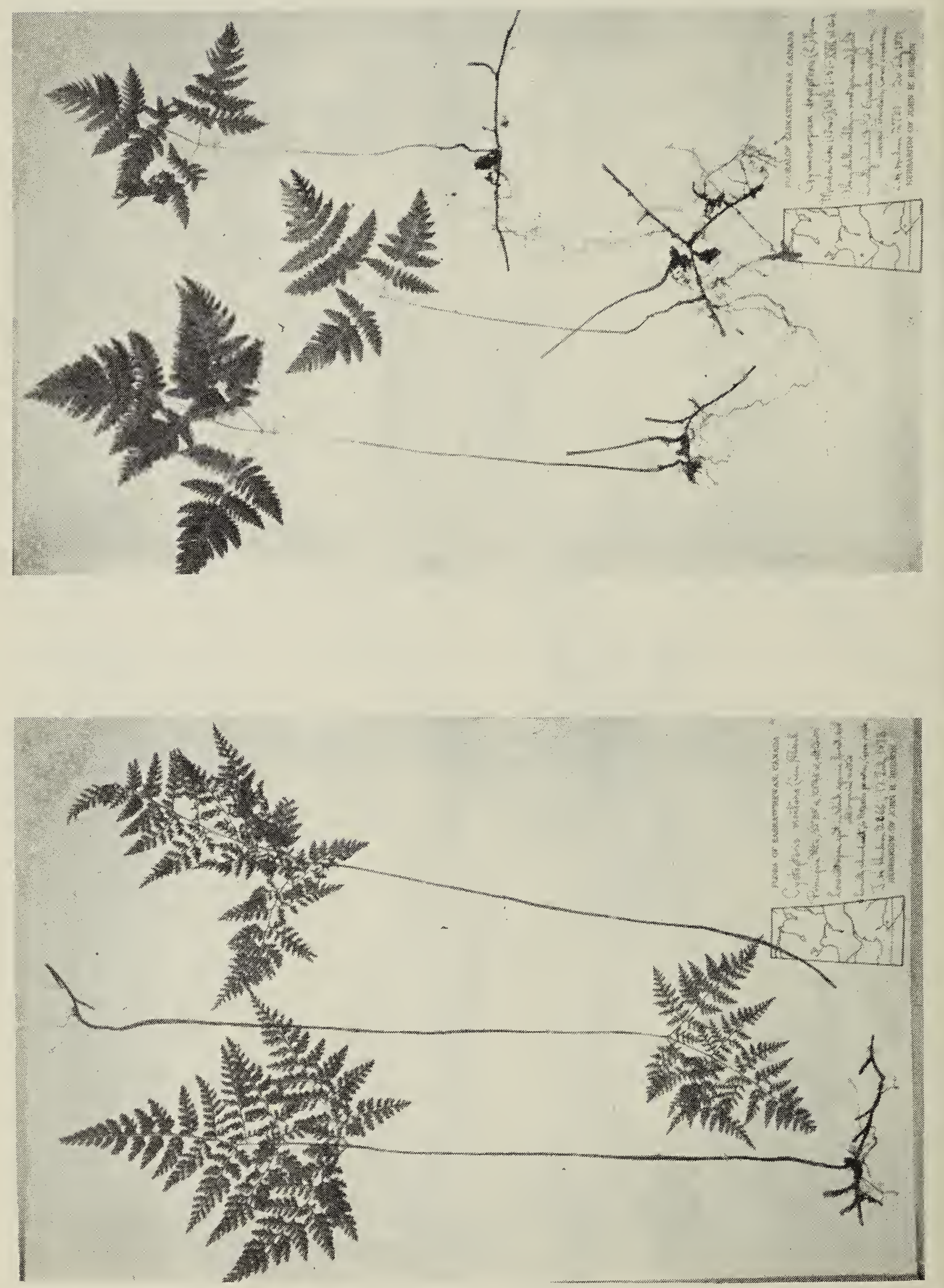


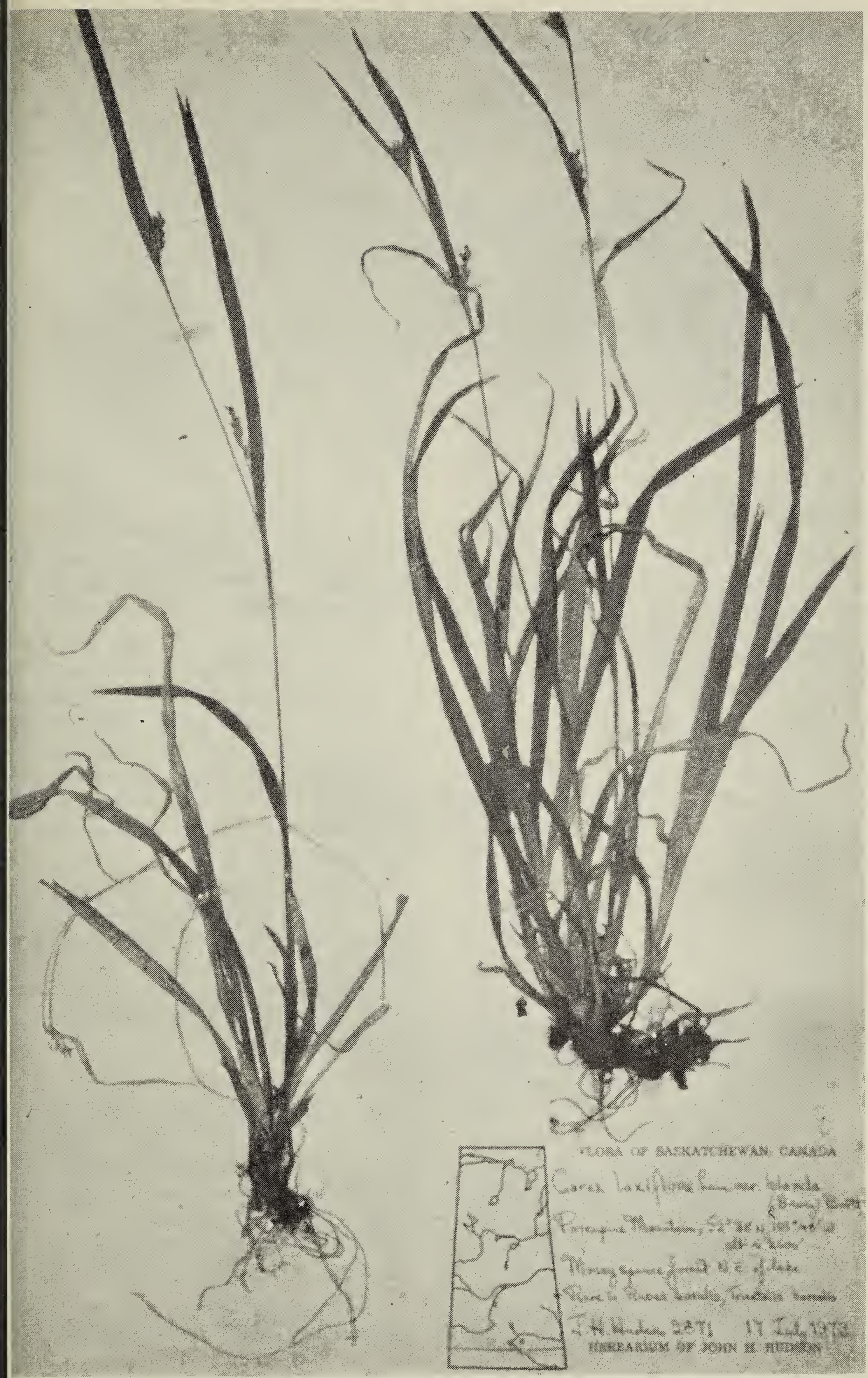

Fig. 4. Carex laxiflora

Decamber, 1974. 32(4) 
that it had by then been collected by J. S. Rowe (personal communication) on Riding Mountain. It is thus not surprising that it should turn up further northwest along the Manitoba Escarpment.

The find of the summer was Cystopteris montana (Lam.) Bernh., Mountain Bladder-Fern, collected as Hudson No. 2866, July 17, 1973, in low wet open spot in black spruce forest, locally abundant with Spinulose Shield Fern (Dryopteris austriaca (Jacq.) Woynar), Porcupine Mountain, $52^{\circ} 38^{\prime} \mathrm{N}, 101^{\circ} 48^{\prime} \mathrm{W}$, alt. 2,600'. This fern falls into the same genus as our common Fragile Fern, Cystopteris fragilis (L.) Bernh, through its reproductive structures but in gross appearance it has no resemblance. With more or less triangular fronds it looks much the Oak Fern (Gymnocarpium dryopteris (L.) Newman), except that the fronds are once more pinnatifid. The photos, Figs. 2 and 3, of herbarium mounts of the two species show the difference. The fern is not known between the Rocky Mountains of Alberta and Thunder Bay, Ontario, according to the distribution map in Hultén.' I had, of course, no idea what it was when I collected it, other than that I didn't know it; it had to be keyed out from scratch using Eastern manuals.

Another plus value was Carex laxiflora Lam. (?) var. blanda (Dewey) Boott, collected as Hudson Ne. 2871, July 17, 1973, in mossy spruce forest on Porcupine Mountain, $52^{\circ} 38^{\prime} \mathrm{N}$, $101^{\circ} 48^{\prime} \mathrm{W}$, alt. 2,600'. This is an eastern woodland sedge. The species, C. laxiflora, is highly variable; Boivin recognized six varieties of it in Eastern Canada, of which he reported only var. blanda as reaching Manitoba." Scoggan gave Manitoba material the status of a full species, C. blanda Dewey, and reported it from Brandon and Whiteshell Forest Reserve." The assignment of my material to var. blanda is done with some doubt an solely on the basis of these publishe reports; the material fits none of th described varieties perfectly. There no point in giving a written descriptio of it; it looks like no familiar specie Some idea of its appearance may $b$ obtained from the photograph of th collection (Fig. 4).

Also at Porcupine Mountain the rar northern sedges Carex loliacea L, Hud son No.2870, and C. pauciflora Lightf Hudson No. 2856, were collected o July 17 and July 1, respectively. Th former has been reported from Lac 1 Ronge and Athabaska Lake b Breitung, the latter from Athabask Lake by Argus." 1

Duplicates of these collections have been sent to the herbaria of the University of Saskatchewan, Saskatoor (Sask.) and of the Dept. of Agriculture Ottawa (DAO).

The records reported here represen a mixture of northern and of eastern species. The eastern species seem to be extensions from their general ranges along the Manitoba escarpment; tho northern ones are undoubtedly a consequence of the altitude of the hills. which are colder and moister than the country at their base. It must be understood, however, that in overall aspect Porcupine Mountain looks just like any other tract of Boreal Forest; only the rowans when in flower give any hint that the plant geography may hold something of interest.

\section{References}

'ARGUS, G. W. 1968. Contributions to the Flora of Boreal Saskatchewan. Rhodora 70: 200-214.

'BOIVIN, B. 1967. Enumération des plantes du Canada. Provancheria No. 6, Universite Laval, Quebec. First published in parts in Le Naturaliste Canadien, Vols. 93 and 94.

:BREITUNG, A. J. 1957. Annotated Catalogue of the Vascular Flora of Saskatchewan. Amer. Midland Naturalist 58: 1-72.

'HULTEN, E. 1968. Flora of Alaska and Neighboring Territories. Stanford University Press, Stanford, California.

¿SCOGGAN, H. J. 1957. Flore of Manitoba. Nat. Mus. Canada Bull. 140. Ottawa, Queen's Printer. 